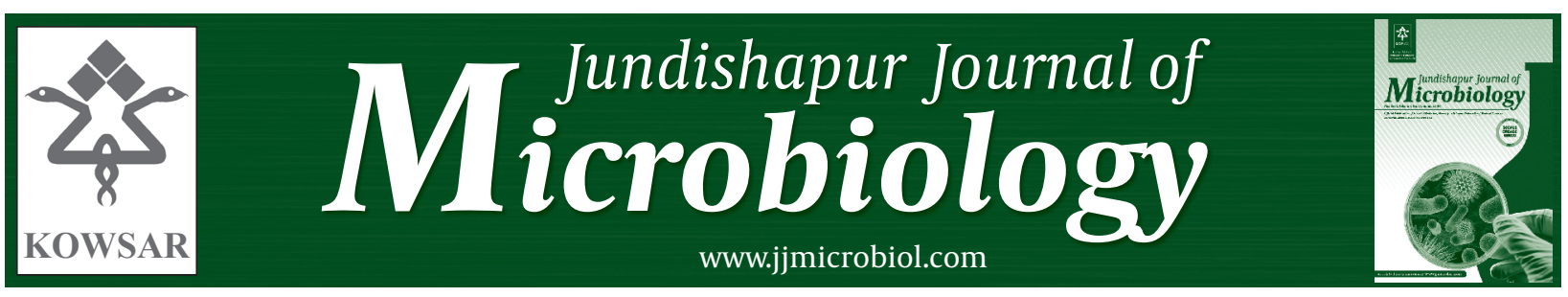

\title{
HBsAg Variants: Common Escape Issues
}

\author{
Payam Dindoost ${ }^{1}$, Seyed Mohammad Jazayeri ${ }^{2}$, Hadi Karimzadeh ${ }^{2}$, Esmaeil Saberfar ${ }^{3}$, \\ Seyed Mohammad Miri ${ }^{4}$, Seyed Moayed Alavian ${ }^{4 *}$ \\ ${ }^{1}$ Iran Hepatitis Network, Tehran, IR Iran \\ ${ }^{2}$ Hepatitis B Molecular Laboratory-Department of Virology-School of Public Health-Tehran University of Medical Sciences, Tehran, IR Iran \\ ${ }^{3}$ Research Center for Applied Virology, Baqiyatallah, University of Medical Sciences, Tehran, IR Iran \\ ${ }^{4}$ Baqiyatallah University of Medical Sciences, Baqiyatallah Research Centre for Gastroenterology and Liver Disease, Tehran, IR Iran
}

\begin{tabular}{l}
\hline A R T I C L E I N F O \\
\hline Article type: \\
Review Article \\
\hline Article history: \\
Received: 25 Jan 2012 \\
Revised: 3 Apr 2012 \\
Accepted: 4 Apr 2012 \\
\hline
\end{tabular}

\section{Keywords:}

HBSAg

Escape Mutant

Blood Donor

Iran

\begin{abstract}
A B S T R A C T
Mutations have been described in all of the four open reading frames of the hepatitis $\mathrm{B}$ virus (HBV), however, from a clinical perspective the surface escape mutant is the most troublesome. Hepatitis B surface antigen (HBsAg) variants may impair diagnosis, or allow the virus to escape vaccine-induced immunity or passive immunoglobulin therapy. HBV mutants with amino acid substitutions, within the common "a" determinant of HBsAg have been identified, and as a result, the HBsAg cannot be detected in some assays (diagnostic-escape). In these situations, the HBsAg mutants may arise in patients with a HBV infection, but they have been diagnosed as HBsAg negative. This review deals with the latest results on the performance of HBsAg assays, as well as the reactivity of native and or recombinant mutants of HBsAg.
\end{abstract}

Published by Kowsar Corp, 2012. cc 3.0.

Implication for health policy/practice/research/medical education:

This molecular review article is suitable for virologists, pathologists and laboratory specialists. It is important for health policy makers to understand the different aspects of HBsAg Variants in HBV vaccination programs. The blood banks should now that these mutations can affect the screening of HBV in blood donors.

- Please cite this paper as:

Dindoost P, Jazayeri SM, Karimzadeh H, Saberfar E, Miri SM, Alavian SM. HBsAg Variants; Common Escape Issues. Jundishapur J Microbiol. 2012;5(4):521-7. DOI: $10.5812 / j \mathrm{jm} .4243$

\section{Background}

Viruses are under constant selection pressure and as a result undergo continual sequence variation. Some of these variants are clinically relevant. The single open reading frame(ORF) that occupies more than one-third of the hepatitis $\mathrm{B}$ virus (HBV) genome encodes the three hepatitis $\mathrm{B}$ surface antigen (HBsAg)-containing polypeptides. Thus, the three envelope proteins can be translated as; L (large), M (middle), and S (small), or HBsAg. Within the latter, the region between amino acids (aa) 100 and 160 is termed as the major hydrophilic region (MHR). This region is comprised of aa 99-160 that encompass the group-specific "a" determinant (Figure 1). The anti-HBs (antibody to HBsAg) response following natural infection or after immunization is comprised mainly of antibodies that recognize the MHR of the protein. Two major loops and one minor loop are proposed in the MHR, and these are defined by multiple potential di-

\footnotetext{
* Corresponding author: Seyed Moayed Alavian, Baqiyatallah University of Medical Sciences, Baqiyatallah Research Centre for Gastroenterology and Liver Disease, Tehran, IR Iran.+98-2188945186-8, Fax:+98-2181262072, E-mail: alavian@thc.com

DOI: $10.5812 / j j m .4243$

(C) 2012 Ahvaz Jundishapur University of Medical Sciences; Published by Kowsar Corp.

This is an Open Access article distributed under the terms of the Creative Commons Attribution License (http://creativecommons.org/licenses/by/3.0), which permits unrestricted use, distribution, and reproduction in any medium, provided the original work is properly cited.
} 
sulfide bridges, between aa 107-137 (or 138), 139.147 (or 149), and 121.124 (Figure 1). The majority of the anti-HBs antibodies that appear after a natural infection are directed against this epitope cluster. The antigenic epitopes of the "a" region have been analyzed by binding studies to synthetic peptides using anti-HBs monoclonal/polyclonal antibodies (1-3) and conserved cysteines at positions 124, 137, 139 and 149 (Figure 1) which have been found to be essential for antigenicity and presumably also for the conformation of the protein (4-8). HBV mutations define an obscure phenomenon. In fact, this occurrence seems to be the potential mechanism for the pathogenic basis of chronicity and the clinical complications of this infection. Thanks to the invention of polymerase chain reactions (PCR), facilities for direct sequencing and other molecular approaches, hundreds of reports have been published so far that reveal the relationship between correspondent mutations and the clinical/serological pictures of the chronic patients. Recent studies have shown that HBsAg is more variable than initially thought, and amino acid exchanges are scattered over the whole molecule.

\section{Objectives}

The primary aims of this review were to; first, classify different aspects of the HBsAg variants. Second, to describe the patterns of mutational distribution, not only within the "a" determinant in a fashion way, but to present some data on this dispersal outside of that domain, as well as those completely outside of the MHR region. Third, to introduce up-to-date information regarding the clinical and transmission aspects of such variants.

\section{Materials and Methods}

Acomprehensive search of PubMed and ISI was performed with the following Mesh term search keywords: HBsAg mutants and a determinant, vaccine escape HBsAg variants. All published data from 1989 (the discovery of surface mu-

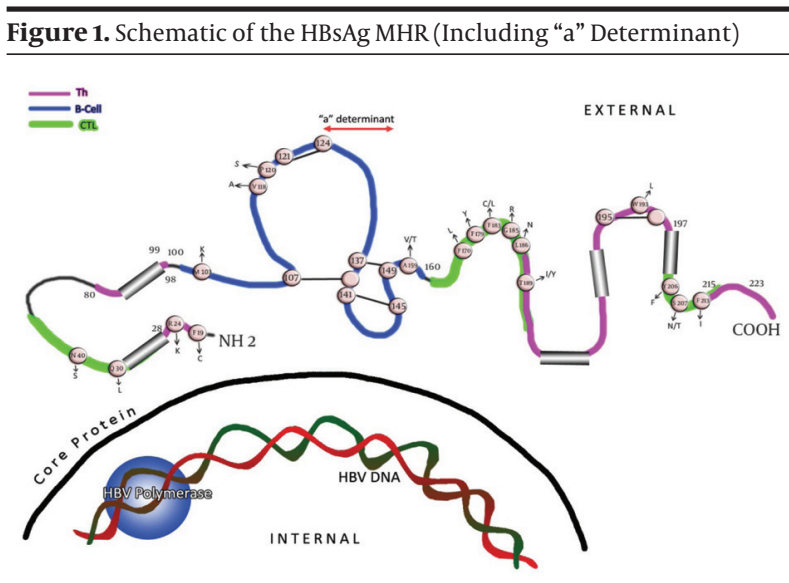

Cysteine residues are shown as white circles and disulphide bridges are indicated as S-S links. The changes selected by antibodies (natural, used in assays and vaccine-induced) that occur upstream and downstream of the determinant are indicated. The carboxyl-terminal end of the protein contains two alpha helices, shown as cylindrical structures. tants) until June 2011, have been included in the study. The inclusion criteria for the study were; mutations affecting vaccine and/or hepatitis B immune globulin (HBIG) escape and horizontal transmission of those variants. Data were analyzed on the basis of amino acid substitutions in different domains of HBsAg in relation to their clinical impact.

\section{Results}

\subsection{HBsAg Escape Mutations}

\subsection{1. "A” Determinant Mutations}

Multiple amino acid changes in the surface-exposed regions of HBsAg, including mutational deletions have been found to abolish the reactivity of monoclonal and poly-

\begin{tabular}{|c|c|c|c|}
\hline Amino Acid Position & Wild-Type & Mutant & Cause \\
\hline 118 & $\mathrm{~T}$ & A & $\mathrm{V}^{\mathrm{a}}$ \\
\hline 120 & $\mathrm{P}$ & $\mathrm{E} / \mathrm{S} / \mathrm{T} / \mathrm{L}$ & $\mathrm{V}-\mathrm{L}^{\mathrm{a}}-\mathrm{HBIG}^{\mathrm{a}}$ \\
\hline 122 & $\mathrm{R}$ & $\mathrm{L}$ & $\mathrm{V}$ \\
\hline 123 & $\mathrm{~T}$ & $\mathrm{~N}$ & HBIG \\
\hline 124 & $\mathrm{C}$ & $\mathrm{R} / \mathrm{Y}$ & HBIG \\
\hline 126 & $\mathrm{I} / \mathrm{T}$ & $\mathrm{A} / \mathrm{N} / \mathrm{S}$ & V-HBIG \\
\hline 127 & $\mathrm{P}$ & $\mathrm{T} / \mathrm{L}$ & V \\
\hline 129 & Q & $\mathrm{H} / \mathrm{L}$ & V-HBIG \\
\hline 130 & G & $\mathrm{D} / \mathrm{R}$ & L-HBIG \\
\hline 131 & $\mathrm{~T}$ & $\mathrm{~A} / \mathrm{N} / \mathrm{I} / \mathrm{P}$ & V \\
\hline 133 & M & $\mathrm{L} / \mathrm{I} / \mathrm{T}$ & V-HBIG \\
\hline 134 & $\mathrm{~F} / \mathrm{Y}$ & $\mathrm{N} / \mathrm{R}$ & HBIG \\
\hline 139 & $\mathrm{C}$ & $\mathrm{Y} / \mathrm{S}$ & V-HBIG \\
\hline 141 & K & $\mathrm{E} / \mathrm{I} / \mathrm{R}$ & V \\
\hline 142 & $\mathrm{P}$ & S & $\mathrm{V}$ \\
\hline 143 & S & $\mathrm{L} / \mathrm{W}$ & V-HBIG \\
\hline 144 & $\mathrm{D}$ & $\mathrm{A} / \mathrm{E}$ & V-HBIG \\
\hline 145 & G & $\mathrm{R} / \mathrm{A}$ & V-L-HBIG \\
\hline 146 & $\mathrm{~N}$ & S & V \\
\hline 147 & C & S & V-HBIG \\
\hline 148 & $\mathrm{~T}$ & I & V \\
\hline 149 & C & $\mathrm{R}$ & V \\
\hline 156 & W & $\mathrm{L} / \mathrm{C}$ & V-HBIG \\
\hline 157 & A & $\mathrm{D} / \mathrm{R}$ & V-L \\
\hline 158 & $\mathrm{~F}$ & $\mathrm{Y} / \mathrm{S}$ & V-L \\
\hline 179 & F & Y & $\mathrm{L}$ \\
\hline 181 & Q & $\mathrm{H}$ & V \\
\hline 183 & $\mathrm{~F}$ & C & V \\
\hline 198 & M & I & $\mathrm{L}$ \\
\hline 204 & $\mathrm{~N}$ & $S$ & V \\
\hline 207 & $\mathrm{Q}$ & $\mathrm{R} / \mathrm{S}$ & $\mathrm{L}$ \\
\hline 208 & I & $\mathrm{T}$ & V \\
\hline 213 & $\mathrm{M}$ & $\mathrm{L} / \mathrm{I} / \mathrm{F}$ & V \\
\hline 218 & I & $\mathrm{S} / \mathrm{L}$ & V \\
\hline
\end{tabular}

a Abbreviations: HBIG, hepatitis B immune globulin; L, lamivudine; V, vaccine. 
clonal anti-HBs diagnostic antibodies against the "a" loop epitope cluster, and most anti-HBs in sera from vaccinees are targeted to an epitope between aa 139 and 147 (9).

Amino acid substitution within the MHR can allow replication of HBV in vaccinated persons, as much of the antibodies induced by current vaccines do not recognize critical changes in this surface antigen domain (10). These variants are summarized in Figure 1 and Table 1. In many studies, mutations in vaccinated children were preferentially located in the "a" determinant $(11,12)$, in contrast to the more randomly located mutations in unvaccinated children $(13,14)$. In general, replacement in the presumed second "a" determinant loop, including aa positions 144 and 145, are more often associated with anti-HBs immune pressure, than mutations in other epitopic domains of the MHR (Figure 1) (5). On the other hand, second "a" determinant loop mutations are unusual in the absence of anti-HBs pressure (15). Mutations at aa positions 120,143,144, and 145 can result in poor reactivity with dly subtyping monoclonal antibodies $(16,17)$. As this specificity is defined by the residue at aa 122 , this indicates the discontinuous nature of many of the epitopes in this antigenic region.

There are linear and discontinuous B-cell epitopes, and some regions are part of more than one epitope. Subtyperelated variations can also alter the binding of antibodies to regions linearly distant $(16,17)$. These differences in the location of mutations may represent the distinctive features of naturally occurring mutations and may suggest the differences in the target epitopes between naturally acquired anti-HBs and those obtained by immunization.

\subsubsection{Mutations outside the " $a$ " Determinant}

Changes located outside the "a" determinant region were reported from immunized infants in Singapore born to HBV carrier mothers $(18,19)$. Interestingly, some of these mutant proteins had reduced binding to monoclonal antibodies against the "a" determinant, and some were most likely transmitted vertically, as they were isolated from both the infant and maternal serum. Their role in vaccination failure is currently unknown. Some of those variants were within the major hydrophilic loop of HBsAg, but mutations at aa positions 183 and 184 were also found. As some of these mutations had decreased binding to an "a"-specific monoclonal antibody, their functional analysis will contribute to the understanding of the antigenic structure of the HBV envelope. Likewise, multiple aa changes in the surface-exposed regions of HBsAg, including mutations and/or deletions upstream and downstream of the "a" determinant region (Figure 1) (20-22), were found to abolish the reactivity of monoclonal and polyclonal anti-HBs diagnostic antibodies against the "a" loop epitope cluster, and they were not recognized by the vaccinee's sera either $(2,3,26)$. The region between aa 118 and 123 was identified as a hot spot for insertions by investigators, illustrating its immuno- logical importance $(2,24,25)$. Furthermore, aa substitutions have been found in residues downstream (38 to 98) and upstream (between 164-215) of the MHR region of native and or recombinant surface proteins with different binding capacity to the antibodies (27-31).

In an attempt to study the sensitivity of modern assays for the detection of HBsAg, investigators have evaluated the performance of different assays for the detection of single, double and triple recombinant and/or native HBsAg mutants (28, 30-34). Assays were challenged with native and/or recombinant HBsAg in positions upstream and downstream of the "a" determinant (Figure 1). Interestingly, the majority of HBsAg tests were able to detect the mutants (data are not shown).

\subsubsection{Mutations in Surface Protein T cell Epitopes}

Being a structural protein, HBsAg is an immune target. The distribution of the mutations within known surface protein immune epitopes reflects the virus-host interaction over a prolonged infection period. HBV surface proteins contain both $\mathrm{B}$ and $\mathrm{T}$ cell antigenic epitopes. Mutations in T cell epitopes may theoretically influence the anti-HBs antibody profile through an interaction between CD4+ helper T cells and B cells (5). Appropriate reactivity of $\mathrm{T}$ cells is a prerequisite for adequate anti-HBs production after infection with the HBV, as well as after hepatitis B vaccination. Thus, the T cell epitopes of HBsAg, being targets for recognition by T cells, should also be affected. The humoral response to HBsAg is T cell-dependent. At least four regions within the HBsAg present epitopes for MHC class II restricted CD4+ T cells (Table 2) $(35,36)$.

The effect of HBsAg T cell epitope variants on the cellular immune response has been studied in individuals vaccinated against HBV by Bauer et al. (37). Six of the 23 different variants in two HBsAg Th epitopes were shown to be responsible for inadequate $\mathrm{T}$ cell reactivity. Similarly, the MHC class I-restricted CDB+CTL response plays a key role in suppressing HBV infections. Schirmbeck et al. (38) showed that in $\mathrm{H}-2 \mathrm{~b}$ mice even small changes in amino acid residues within the two different CTL epitopes that mimic natural variants of adw2, ayr and adr, completely

\begin{tabular}{llll}
\hline \multicolumn{4}{l}{ Table 2. Proposed Antigenic Epitopes within HBsAg. } \\
\hline Sequence & Cell subsets & HLA restriction & Ref \\
\hline $100-160$ & B & non HLA restriction & $(91)$ \\
$19-28$ & Th & Class $\Pi$ & $(34)$ \\
$28-51$ & CTL & Class I HLA-A2 & $(40)$ \\
$80-98$ & Th & Class $\Pi$ & $(34)$ \\
$171-179$ & CTL & Class I & $(39)$ \\
$175-184$ & CTL & Class I HLA-A2 & $(35)$ \\
$186-197$ & Th & Class П & $(35)$ \\
$206-215$ & CTL & Class I HLA-A2 & $(35)$ \\
$215-223$ & Th & Class П & $(35)$ \\
\hline
\end{tabular}


eliminated the immunogenicity of each epitope. A majority of mutations found up- and downstream of MHR in different studies were found to be potentially responsible for vaccine breakthroughs. HBsAg undetectability (2, $3,20,23,39$ ) were found to be located within the known, either Th or CTL (or both), epitopes of the surface protein (Table 2) $(35,36,40,41)$.

In general, viral mutations in CTL epitopes were able to evade cellular immunity and thus contribute to persistency $(42,43)$. Naturally occurring mutations within the CTL epitope could lead to epitope inactivation and T cell receptor antagonism (44). Studies from our laboratory have revealed a high frequency of mutations at aa positions of the surface gene that coincides with the HLArestricted CTL epitope in patients with chronic hepatitis $\mathrm{B}$, suggesting that these mutations might contribute to chronic infections (45). Nonetheless, accumulating evidence indicates that the genomic heterogeneity of the virus does not account for HBsAg negative status in all cases $(25,39,46)$.

\subsubsection{Mutation in Other HBV Proteins}

In other studies, however, the failure of HBsAg detection was not fully explained by surface (S) gene mutations ( 47 , 48). Furthermore, multiple mutations outside the surface protein could be found within the core, pre-S, X and polymerase with known functional and/or immune epitope reactivity $(39,49,50)$.

Multiple alterations in the genome possibly have a synergistic effect in the downregulation of HBsAg production, and an isolated cause for mutation in a particular gene or regulatory region could not be established. Thus, it appears that the nondetectability of HBsAg in serum may arise as a result of several mechanisms caused by alterations in the; structural, functional, and regulatory regions of the HBV genome, causing it to lie below the sensitivity of standard enzyme-linked immunosorbent assay tests $(46,51,52)$. Mutations outside the surface protein may also influence HBV replication capacity. According to earlier studies, these mutants have also been reported to be less "replication fit," compared to wild-type viruses in vitro, providing a plausible explanation for the low HBV DNA levels $(53,54)$.

\section{Clinical Aspects of HBsAg Mutants}

\subsection{Chronic State}

Little is known about the natural history of HBsAg variants. The presence or absence of HBsAg variants in chronic patients (i.e., children, inactive carriers, chronic active carriers, etc.) has created a confounding scenario. Some reports have suggested that patients with pure or mixed "a" epitope variants had lower alanine transaminase (ALT) levels compared with those with wild-type HBV-DNA (55). Asian-Indian patients with HBsAg variants had a prolonged illness in the form of anicteric chronic hepatitis. These patients had a higher frequency of quiescent cirrhosis and hepatocellular carcinoma than those with the wild-type hepatitis B virus. On the other hand, S-gene mutants have been associated with an aggressive or worsening clinical course in some reports $(56,57)$. Further analysis is required to assess the association of "a" epitope variants with the development of liver diseases.

A number of escape-variant viruses during the course of chronic infection within the "a" determinant were reported to be replicated in spite of the presence of antiHBs $(15,39,58-68)$. This phenomenon, which has been explored by molecular approaches in vaccinated individuals, may result from at least seven reasons. First, individuals protected by HBV vaccines had a low capacity of immune response (in early childhood) and they could not develop enough anti-HBs antibodies. Second, the blood of newborn babies had already been contaminated with $\mathrm{HBV}$ particles in the uterus, so that the HBV vaccines were ineffective. The third situation could be the infection of HBV mutants or simultaneous infections with wild types. These mutants may present as a small percentage, a minor strain together with the predominant wild-type strain, either before the onset of antibody-mediated immune pressure and thus are merely selected, or they may emerge under conditions unfavorable for wild-type virus, which cannot be detected through the use of sequencing analysis. Fourth, mutations within the surface gene are one of the factors contributing to a loss of HBsAg detection by immunoassay (diagnostic-escape mutants). These "a" determinant variants may go undetected by conventional HBsAg screening tests. Sixth, the anti-HBs in these patients may possibly be directed against the epitopes outside the "a" determinant, such as $d / y$ or w/r subtype determinants (66). Seventh, low expression of HBsAg due to a low viral load (which might be just enough for viral assembly, but underneath the sensitivity of standard tests) thus moving it below the sensitivity of standard serologic assays (69). In some cases, mutations in the "a" determinant have been seen without the presence of antiHBs. The lack of serum anti-HBs in these patients does not necessarily indicate a lack of humoral immune responses to the "a" determinant, because it has been reported that anti-HBs can be complexed with HBsAg (and detection of one or the other alone merely indicates dominance at that time) $(66,70,71)$. Therefore, the data suggests that escape mutations could be induced by immunological pressure exerted on the MHR (within or up and downstream of the "a" determinant), even in patients who are found to be negative for serum anti-HBs through the use of the usual assay.

\subsection{Transmission}

Blood safety issues related to the safety of the blood or tissues of an HBsAg-negative donor and the risk of trans- 
mission are of grave concern. There is a fear that escape mutants may be spread by blood transfusion, since HBV DNA detection by nucleic acid amplification technology (NAT) is not mandatory for blood donor screening in many countries, especially in those areas where the prevalence of escape mutants is expected to be high. Earlier studies clearly indicated that the transfusion of blood containing HBsAg has been associated with the development of post transfusion hepatitis B (72-74), and that cases of HBV infection have been identified after transfusion of a HBsAg negative blood supply (75-77). Moreover, it is well known that mutants of HBsAg are able to cause infection and horizontal transmission despite the presence of anti-HBs (78-82).

Studies in both animals and humans have proven that the G145R mutant can infect the host without the help of a wild type virus $(83,84)$. This suggests that the native conformation of the second "a" loop is not essential, at least for the entrance of the virus into the cell. As a consequence it may be argued that the second "a"-loop related antibodies may not be protective on their own, although they may lower the viral load in the circulation by the formation of aggregates that are easily opsonized (81). Escape mutants may breakthrough vaccine programs and spread locally (85). The issue of whether the current vaccine is effective in preventing infection by these mutants, particularly in infants born to HBV carrier mothers, is currently under debate $(13,42,86,87)$. Of particular concern is the observed emergence of "a" determinant mutants occurring in geographic regions where universal vaccination has been instituted $(14,88)$.

Although the absolute number of new infections has been reduced in these regions, infections are most often observed in vaccinated infants born to HBV carrier mothers, suggesting that infants exposed to a maternal mutant virus may select for this strain during the development of vaccine-induced antibodies $(39,89)$. An epidemiological model of the HBV that investigated possible patterns of emergence of a vaccine-resistant strain, showed that using pessimistic assumptions (i.e., the current vaccine provides no cross-immunity against the variant), the variant would not become dominant over the wild-type for at least 50 years $(90)$.

\section{Conclusions}

In conclusion, mutations have been described in all of the four open reading frames of the HBV. Thus, from a clinical perspective, the $S$ escape mutant is the most troublesome, because in the absence of surveillance systems and/or a high index of suspicion, a diagnosis can be difficult to establish. A HBV genome containing mutated immune epitopes can no longer be recognized by specific $\mathrm{T}$ cells of the host immune surveillance and they will not enhance anti-HBs production; this could lead to the progression of chronicity of the HBV infection.

\section{Acknowledgements}

None Declared.

\section{Financial Disclosure}

None Declared.

\section{Funding Support}

None Declared.

\section{References}

1. Ijaz S, Ferns RB, Tedder RS. A 'first loop' linear epitope accessible on native hepatitis $B$ surface antigen that persists in the face of 'second loop' immune escape.J Gen Virol. 2003;84(Pt 2):269-75.

2. Kfoury Baz EM, Zheng J, Mazuruk K, Van Le A, Peterson DL. Characterization of a novel hepatitis B virus mutant: demonstration of mutation-induced hepatitis B virus surface antigen group specific "a" determinant conformation change and its application in diagnostic assays. Transfus Med. 2001;11(5):355-62.

3. Zheng X, Weinberger KM, Gehrke R, Isogawa M, Hilken G, Kemper T, et al. Mutant hepatitis B virus surface antigens (HBsAg) are immunogenic but may have a changed specificity. Virology. 2004;329(2):454-64.

4. Ashton-Rickardt PG, Murray K. Mutations that change the immunological subtype of hepatitis B virus surface antigen and distinguish between antigenic and immunogenic determination. J Med Virol.1989;29(3):204-14.

5. Cooreman MP, Leroux-Roels G, Paulij WP. Vaccine- and hepatitis B immune globulin-induced escape mutations of hepatitis $B$ virus surface antigen. J Biomed Sci. 2001;8(3):237-47.

6. Gerin JL, Alexander H, Shih JW, Purcell RH, Dapolito G, Engle R, et al. Chemically synthesized peptides of hepatitis B surface antigen duplicate the $\mathrm{d} / \mathrm{y}$ specificities and induce subtypespecific antibodies in chimpanzees. Proc Natl Acad Sci U S A. 1983;80(8):2365-9

7. Mangold CM, Unckell F, Werr M, Streeck RE. Secretion and antigenicity of hepatitis B virus small envelope proteins lacking cysteines in the major antigenic region. Virology. 1995;211(2):535-43.

8. Prange R, Mangold CM, Hilfrich R, Streeck RE. Mutational analysis of HBsAg assembly. Intervirology. 1995;38(1-2):16-23

9. Howard CR BS, Hogben D, Zuckerman A, Murray-Lyon I, Steward M. Analysis of antibody responses to hepatitis B surface antigen. Hoofnagle JH editor. Orlando: Grune \& Stratton, editor.; 1994.

10. Zuckerman JN, Zuckerman AJ. Mutations of the surface protein of hepatitis B virus. Antiviral Res. 2003;60(2):75-8.

11. Nainan OV, Khristova ML, Byun K, Xia G, Taylor PE, Stevens CE, et $a l$. Genetic variation of hepatitis $B$ surface antigen coding region among infants with chronic hepatitis B virus infection. J Med Virol. 2002;68(3):319-27.

12. Seddigh-Tonekaboni S, Lim WL, Young B, Hou JL, Waters J, Luo $\mathrm{KX}$, et al. Hepatitis B surface antigen variants in vaccinees, blood donors and an interferon-treated patient. $J$ Viral Hepat. 2001;8(2):154-8.

13. Hino K, Katoh Y, Vardas E, Sim J, Okita K, Carman WF. The effect of introduction of universal childhood hepatitis B immunization in South Africa on the prevalence of serologically negative hepatitis B virus infection and the selection of immune escape variants. Vaccine. 2001;19(28-29):3912-8.

14. Hsu HY, Chang MH, Liaw SH, Ni YH, Chen HL. Changes of hepatitis B surface antigen variants in carrier children before and after universal vaccination in Taiwan. Hepatology. 1999;30(5):1312-7

15. Yamamoto K, Horikita M, Tsuda F, Itoh K, Akahane Y, Yotsumoto $\mathrm{S}$, et al. Naturally occurring escape mutants of hepatitis B virus with various mutations in the $S$ gene in carriers seropositive for antibody to hepatitis B surface antigen. J Virol. 1994;68(4):2671-6.

16. Okamoto H, Omi S, Wang Y, Itoh Y, Tsuda F, Tanaka T, et al. The loss of subtypic determinants in alleles, $\mathrm{d} / \mathrm{y}$ or $\mathrm{w} / \mathrm{r}$, on hepatitis $\mathrm{B}$ 
surface antigen. Mol Immunol.1989;26(2):197-205

17. Wallace LA, Echevarria JE, Echevarria JM, Carman WF. Molecular characterization of envelope antigenic variants of hepatitis B virus from Spain. J Infect Dis. 1994;170(5):1300-3.

18. Oon CJ, Chen WN. Current aspects of hepatitis B surface antigen mutants in Singapore. J Viral Hepat. 1998;5 Suppl 2:17-23.

19. Chong-Jin O, Wei Ning C, Shiuan K, Gek Keow L. Identification of hepatitis B surface antigen variants with alterations outside the "a" determinant in immunized Singapore infants. J Infect Dis. 1999;179(1):259-63.

20. Chen WN, Oon CJ, Lim GK. Frequent occurrence of hepatitis B virus surface antigen mutants in subtype adw in vaccinated Singapore infants. Vaccine. 2001;20(5-6):639-40.

21. De Meyer S, Depla E, Maertens G, Soumillion A, Yap SH. Characterization of small hepatitis B surface antigen epitopes involved in binding to human annexin V.J Viral Hepat. 1999;6(4):277-85.

22. Fujiyama A, Miyanohara A, Nozaki C, Yoneyama T, Ohtomo N, Matsubara K. Cloning and structural analyses of hepatitis B virus DNAs, subtype adr. Nucleic Acids Res. 1983;11(13):4601-10.

23. El Chaar M, Candotti D, Crowther RA, Allain JP. Impact of hepatitis $B$ virus surface protein mutations on the diagnosis of occult hepatitis B virus infection. Hepatology. 2010;52(5):1600-10.

24. Grethe S, Monazahian M, Bohme I, Thomssen R. Characterization of unusual escape variants of hepatitis B virus isolated from a hepatitis B surface antigen-negative subject. $J$ Virol. 1998;72(9):7692-6.

25. Chen WN, Oon CJ. Hepatitis B virus surface antigen (HBsAg) mutants in Singapore adults and vaccinated children with high anti-hepatitis B virus antibody levels but negative for HBsAg. J Clin Microbiol. 2000;38(7):2793-4.

26. Hou J, Karayiannis P, Waters J, Luo K, Liang C, Thomas HC. A unique insertion in the $S$ gene of surface antigen-negative hepatitis B virus Chinese carriers. Hepatology.1995;21(2):273-8.

27. Ireland JH, O'Donnell B, Basuni AA, Kean JD, Wallace LA, Lau GK, et al. Reactivity of 13 in vitro expressed hepatitis B surface antigen variants in 7 commercial diagnostic assays. Hepatology. 2000;31(5):1176-82.

28. Muhlbacher A, Weber B, Burgisser P, Eiras A, Cabrera J, Louisirirotchanakul S, et al. Multicenter study of a new fully automated HBsAg screening assay with enhanced sensitivity for the detection of HBV mutants. Med Microbiol Immunol. 2008;197(1):55-6

29. Roohi A, Yazdani Y, Khoshnoodi J, Jazayeri SM, Carman WF, Chamankhah $\mathrm{M}$, et al. Differential reactivity of mouse monoclonal anti-HBs antibodies with recombinant mutant HBs antigens. World J Gastroenterol. 2006;12(33):5368-74.

30. Scheiblauer H, El-Nageh M, Diaz S, Nick S, Zeichhardt H, Grunert $\mathrm{HP}$, et al. Performance evaluation of 70 hepatitis B virus (HBV) surface antigen (HBsAg) assays from around the world by a geographically diverse panel with an array of HBV genotypes and HBsAg subtypes. Vox Sang. 2010;98(3 Pt 2):403-14.

31. Weber B, Van der Taelem-Brule N, Berger A, Simon F, Geudin M, Ritter J. Evaluation of a new automated assay for hepatitis B surface antigen (HBsAg) detection VIDAS HBsAg Ultra. J Virol Methods. 2006;135(1):109-17.

32. Jeantet D, Chemin I, Mandrand B, Tran A, Zoulim F, Merle P, et al. Cloning and expression of surface antigens from occult chronic hepatitis B virus infections and their recognition by commercial detection assays. J Med Virol. 2004;73(4):508-15.

33. Yuana Y, Bertina RM, Osanto S. Pre-analytical and analytical issues in the analysis of blood microparticles. Thromb Haemost. 2010;105(3).

34. Yuan Q, Ge S, Xiong J, Yan Q, Li Z, Hao X, et al. A novel immunoassay for PreS1 and/or core-related antigens for detection of HBsAg variants. J Virol Methods. 2010;168(1-2):108-13.

35. Ducos J, Bianchi-Mondain AM, Pageaux G, Conge AM, Poncet R, Vendrell JP, et al. Hepatitis B virus (HBV)-specific in vitro antibody production by peripheral blood mononuclear cells (PBMC) after vaccination by recombinant hepatitis B surface antigen (rHBsAg). Clin Exp Immunol. 1996;103(1):15-8.

36. Mancini-Bourgine $\mathrm{M}$, Fontaine $\mathrm{H}$, Brechot $\mathrm{C}$, Pol S, Michel ML. Immunogenicity of a hepatitis B DNA vaccine administered to chronic HBV carriers. Vaccine. 2006;24(21):4482-9.

37. Bauer T, Weinberger K, Jilg W. Variants of two major T cell epitopes within the hepatitis B surface antigen are not recognized by specific $\mathrm{T}$ helper cells of vaccinated individuals. Hepatology. 2002;35(2):455-65.

38. Schirmbeck R, Dikopoulos N, Kwissa M, Leithauser F, Lamberth $\mathrm{K}$, Buus S, et al. Breaking tolerance in hepatitis B surface antigen (HBsAg) transgenic mice by vaccination with cross-reactive, natural HBsAg variants. Eur J Immunol. 2003;33(12):3342-52.

39. Shahmoradi S, Yahyapour Y, Mahmoodi M, Alavian SM, Fazeli Z, Jazayeri SM. High prevalence of occult hepatitis B virus infection in children born to HBsAg-positive mothers despite prophylaxis with hepatitis B vaccination and HBIG. J Hepatol. 2012;57(3):515-21.

40. Barnaba V, Franco A, Paroli M, Benvenuto R, De Petrillo G, Burgio $\mathrm{VL}$, et al. Selective expansion of cytotoxic T lymphocytes with a $\mathrm{CD} 4+\mathrm{CD} 56+$ surface phenotype and a Thelper type 1 profile of cytokine secretion in the liver of patients chronically infected with Hepatitis B virus. J Immunol. 1994;152(6):3074-87.

41. Tai PC, Banik D, Lin GI, Pai S, Pai K, Lin MH, et al. Novel and frequent mutations of hepatitis B virus coincide with a major histocompatibility complex class I-restricted T-cell epitope of the surface antigen.J Virol. 1997;71(6):4852-6.

42. Zuckerman AJ. Effect of hepatitis B virus mutants on efficacy of vaccination. Lancet. 2000;355(9213):1382-4.

43. Franzese O, Kennedy PTF, Gehring AJ, Gotto J, Williams R, Maini MK, et al. Modulation of the CD8+-T-Cell Response by CD4+CD25+ Regulatory T Cells in Patients with Hepatitis B Virus Infection. Virol. 2005;79(6):3322-8.

44. Bertoletti A, Sette A, Chisari FV, Penna A, Levrero M, De Carli M, et al. Natural variants of cytotoxic epitopes are T-cell receptor antagonists for antiviral cytotoxic T cells. Nature.1994;369(6479):407-10.

45. Sayad B, Anvari FA, Alavian SM, Norouzi M, Hamzelooie M Shirvani M, et al. Correlation of Hepatitis B surface antigen mutations with clinical status of the chronically infected patients from Kermanshah, West of Iran. Minerva Gastroenterol Dietol. 2012;58(1):9-18.

46. Pollicino T, Raffa G, Costantino L, Lisa A, Campello C, Squadrito G, et al. Molecular and functional analysis of occult hepatitis B virus isolates from patients with hepatocellular carcinoma. Hepatol ogy. 2007; 45(2):277-85.

47. Banerjee A, Chandra PK, Datta S, Biswas A, Bhattacharya P, Chakraborty S, et al. Frequency and significance of hepatitis B virus surface gene variant circulating among 'antiHBc only' individuals in Eastern India. J Clin Virol. 2007;40(4):312-7.

48. Brojer E, Grabarczyk P, Liszewski G, Mikulska M, Allain JP, Letowska M. Characterization of HBV DNA+/HBsAg-blood donors in Poland identified by triplex NAT. Hepatology. 2006;44(6):1666-74.

49. Jazayeri SM. Commentary on: A study of genotype, mutants and nucleotide sequence of HBV in Pakistan: Genotype, mutants, and nucleotide sequence of HBV. Hepat Mon. 2011;11(4):289-91. Epub 2011/11/17.

50. Carman WF, Thomas HC. Genetic variation in hepatitis B virus. Gastroenterology.1992;102:9.

51. Chaudhuri V, Tayal R, Nayak B, Acharya SK, Panda SK. Occult hepatitis B virus infection in chronic liver disease: full-length genome and analysis of mutant surface promoter. Gastroenterology. 2004;127(5):1356-71.

52. Schories M, Peters $\mathrm{T}$, Rasenack J. Isolation, characterization and biological significance of hepatitis B virus mutants from serum of a patient with immunologically negative HBV infection. J Hepatol. 2000;33(5):799-811.

53. Pollicino T, Belloni L, Raffa G, Pediconi N, Squadrito G, Raimondo $\mathrm{G}$, et al. Hepatitis B virus replication is regulated by the acetylation status of hepatitis B virus cccDNA-bound $\mathrm{H} 3$ and $\mathrm{H} 4$ histones. Gastroenterology. 2006;130(3):823-37.

54. Sheldon J, Rodes B, Zoulim F, Bartholomeusz A, Soriano V. Mutations affecting the replication capacity of the hepatitis B virus. Viral Hepat. 2006;13(7):8.

55. Guptan RC, Thakur V, Sarin SK, Banerjee K, Khandekar P. Frequency and clinical profile of precore and surface hepatitis B mutants in Asian-Indian patients with chronic liver disease. Am J Gastroen- 
terol.1996;91(7):1312-7.

56. Kalinina T, Riu A, Fischer L, Will H, Sterneck M. A dominant hepatitis $B$ virus population defective in virus secretion because of several S-gene mutations from a patient with fulminant hepatitis. Hepatology. 2001;34(2):385-94

57. Ngui SL, Hallet R, Teo CG. Natural and iatrogenic variation in hepatitis B virus. Rev Med Virol.1999;9(3):183-209.

58. Bahn A, Gerner P, Martine U, Bortolotti F, Wirth S. Detection of different viral strains of hepatitis B virus in chronically infected children after seroconversion from HBsAg to anti-HBs indicating viral persistence. J Hepatol. 1997;27(6):973-8.

59. Brind A, Jiang J, Samuel D, Gigou M, Feray C, Brechot C, et al. Evidence for selection of hepatitis B mutants after liver transplantation through peripheral blood mononuclear cell infection. $J$ Hepatol.1997;26(2):228-35.

60. Carman WF, Korula J, Wallace L, MacPhee R, Mimms L, Decker R. Fulminant reactivation of hepatitis $B$ due to envelope protein mutant that escaped detection by monoclonal HBsAg ELISA. Lancet. 1995;345(8962):1406-7.

61. Carman WF, Trautwein C, van Deursen FJ, Colman K, Dornan E, McIntyre G, et al. Hepatitis B virus envelope variation after transplantation with and without hepatitis B immune globulin prophylaxis. Hepatology.1996;24(3):489-93.

62. Carman WF, Zanetti AR, Karayiannis P, Waters J, Manzillo G, Tanzi $\mathrm{E}$, et al. Vaccine-induced escape mutant of hepatitis B virus. Lancet. 1990;336(8711):325-9.

63. Ghany MG, Ayola B, Villamil FG, Gish RG, Rojter S, Vierling JM, et al. Hepatitis B virus $S$ mutants in liver transplant recipients who were reinfected despite hepatitis B immune globulin prophylaxis. Hepatology. 1998;27(1):213-22

64. Hsu HY, Chang MH, Ni YH, Lin HH, Wang SM, Chen DS. Surface gene mutants of hepatitis $B$ virus in infants who develop acute or chronic infections despite immunoprophylaxis. Hepatology. 1997;26(3):786-91.

65. Karthigesu VD, Allison LM, Fortuin M, Mendy M, Whittle HC, Howard CR. A novel hepatitis B virus variant in the sera of immunized children. J Gen Virol. 1994;75 ( Pt 2):443-8.

66. Kohno H, Inoue T, Tsuda F, Okamoto H, Akahane Y. Mutations in the envelope gene of hepatitis B virus variants co-occurring with antibody to surface antigen in sera from patients with chronic hepatitis B. J Gen Virol. 1996;77 ( Pt 8):1825-31.

67. Protzer-Knolle U, Naumann U, Bartenschlager R, Berg T, Hopf U, Meyer zum Buschenfelde $\mathrm{KH}$, et al. Hepatitis B virus with antigenically altered hepatitis B surface antigen is selected by high-dose hepatitis B immune globulin after liver transplantation. Hepatology. 1998;27(1):254-63.

68. Sterneck M, Gunther S, Gerlach J, Naoumov NV, Santantonio T, Fischer L, et al. Hepatitis B virus sequence changes evolving in liver transplant recipients with fulminant hepatitis. $J$ Hepatol. 1997;26(4):754-64

69. Chen WN, Oon CJ, Koh S. Horizontal transmission of a hepatitis B virus surface antigen mutant. J Clin Microbiol. 2000;38(2):938-9.

70. Ackerman Z, Wands JR, Gazitt Y, Bre chot C, Kew MC, Shouval D. Enhancement of HBsAg detection in serum of patients with chronic liver disease following removal of circulating immune complexes. J Hepatol. 1994;20:7.

71. Joller-Jemelka HI, Wicki AN, Grob PJ. Detection of HBs antigen in "anti-HBc alone" positive sera. J Hepatol.1994;21(2):269-72.

72. Gharehbaghian A. An estimate of transfusion-transmitted infection prevalence in general populations. Hepat Mon. 2011;11(12):1002-3.

73. Katchaki JN, Siem TH, Brouwer R, Brandt KH, van der Waart M Detection and significance of anti-HBc in the blood bank; pre- liminary results of a controlled prospective study.JVirol Methods. 1980;2(1-2):119-25.

74. Yoshiba M, Sekiyama K, Sugata F, Kawamoto Y, Muraoka H, Aoyama M. Post-transfusion fulminant hepatitis B after screening for hepatitis B virus core antibody. Lancet. 1992;339(8787):253-4.

75. Liu CJ, Chen DS, Chen PJ. Epidemiology of HBV infection in Asian blood donors: emphasis on occult HBV infection and the role of NAT. J Clin Virol. 2006;36 Suppl 1:S33-44

76. Mosley JW, Stevens CE, Aach RD, Hollinger FB, Mimms LT, Solomon LR, et al. Donor screening for antibody to hepatitis B core antigen and hepatitis $B$ virus infection in transfusion recipients. Transfusion. 1995;35(1):5-12.

77. Hollinger FB. Hepatitis B virus infection and transfusion medicine: science and the occult. Transfusion. 2008;48(5):1001-26.

78. Burda MR, Gunther S, Dandri M, Will H, Petersen J. Structural and functional heterogeneity of naturally occurring hepatitis B virus variants. Antiviral Res. 2001;52(2):125-38.

79. Coleman PF, Chen YC, Mushahwar IK. Immunoassay detection of hepatitis B surface antigen mutants. J Med Virol. 1999;59(1):19-24.

80. Heijtink RA, van Bergen P, van Roosmalen MH, Sunnen CM, Paulij WP, Schalm SW, et al. Anti-HBs after hepatitis B immunization with plasma-derived and recombinant DNA-derived vaccines: binding to mutant HBsAg. Vaccine. 2001;19(27):3671-80.

81. Torresi J, Earnest-Silveira L, Civitico G, Walters TE, Lewin SR, Fyfe $\mathrm{J}$, et al. Restoration of replication phenotype of lamivudineresistant hepatitis B virus mutants by compensatory changes in the "fingers" subdomain of the viral polymerase selected as a consequence of mutations in the overlapping $\mathrm{S}$ gene. Virology. 2002;299(1):88-99

82. Francois G, Kew M, Van Damme P, Mphahlele MJ, Meheus A. Mutant hepatitis B viruses: a matter of academic interest only or a problem with far-reaching implications? Vaccine. 2001;19(2829):3799-815

83. Ogata N, Cote PJ, Zanetti AR, Miller RH, Shapiro M, Gerin J, et al. Licensed recombinant hepatitis B vaccines protect chimpanzees against infection with the prototype surface gene mutant of hepatitis B virus. Hepatology. 1999;30(3):779-86.

84. Ogata N, Zanetti AR, Yu M, Miller RH, Purcell RH. Infectivity and pathogenicity in chimpanzees of a surface gene mutant of hepatitis B virus that emerged in a vaccinated infant. J Infect Dis. 1997;175(3):511-23.

85. Whittle HC, Inskip H, Hall AJ, Mendy M, Downes R, Hoare S. Vaccination against hepatitis $\mathrm{B}$ and protection against chronic viral carriage in The Gambia. Lancet. 1991;337(8744):747-50.

86. Ho M, Mau Y, Lu C, Huang S, Hsu L, Lin S, et al. Patterns of circulating hepatitis B surface antigen variants among vaccinated children born to hepatitis B surface antigen carrier and non-carrier mothers. A population-based comparative study. J Biomed Sci. 1998;5(5):355-62.

87. Purcell RH. Hepatitis B virus mutants and efficacy of vaccination. The Lancet. 2000;356(9231):769.

88. Oon CJ, Lim GK, Ye Z, Goh KT, Tan KL, Yo SL, et al. Molecular epidemiology of hepatitis B virus vaccine variants in Singapore. Vaccine. 1995;13(8):699-702.

89. Ghaziasadi A, Alavian SM, Fazeli Z, Jazayeri SM, editors. Mutational analysis of HBsAg-positive mothers and their children who are infected despite immunoprophylaxis. 4th International Tehran Hepatitis Congress; 2011.

90. Wilson JN, Nokes DJ, Carman WF. The predicted pattern of emergence of vaccine-resistant hepatitis B: a cause for concern? Vaccine. 1999;17(7-8):973-8.

91. Honorati MC, Facchini A. Immune response against HBsAg vaccine. World J Gastroenterol. 1998;4(6):464-6. 